\title{
Parenting Styles of Fishermen and Female Migrant Workers (TKW) Families in Instilling Religious Characters for the Children's
}

\author{
Nailul Ghufron Aziz \\ Socio-Religous Reseacher \\ nailulghufron1995@gmail.com
}

\begin{abstract}
This study aims to determine the types of parenting for the families of fishermen and Female Migrant Workers $(T K W)$ as well as the driving and inbibiting factors in the formation of religious character in children. This research is a field research using a qualitative approach. The data in this study were obtained through interviews, observation, and documentation. The results of this study indicate that: First, the parenting styles used by several mothers in fishermen families are authoritarian, militaristic, democratic, purposeful, and paternalistic. The parenting styles used by fathers in TKW families are role-transfer, laissez-faire, transactional, and affiliation. Second, there are several driving and inhibiting factors in the formation of religious character in children. These factors are the structure of the physical environment, social environment, educational environment, psychological atmosphere in the family, socio-culture in the family, and parental control of their children. The success of these factors is influenced by parent's attention. Parents who care about their children tend to have success in all elements of environmental structures. On the other hand, parents who are indifferent to their families tend to fail in all elements of structures.
\end{abstract}

Keywords: Parenting; Fisherman Family; TKW Family; Religious Character.

\begin{abstract}
Abstrak
Penelitian ini bertujuan mengetahui jenis pola asuh pada keluarga Nelayan dan Pekerja Migran Wanita (TKW) serta faktor pendorong dan penghambat pembentukan karakter religius pada anak. Penelitian ini merupakan penelitian lapangan dengan pendekatan kualitatif. Data dalam penelitian ini diperoleh melalui wawancara, observasi, dan dokumentasi. Hasil penelitian ini menunjukkan bahwa: Pertama, pola asuh yang digunakan oleb beberapa ibu dalam keluarga nelayan adalah otoriter, militeristik, demokratis, bertujuan, dan paternalistik. Pola asub yang digunakan ayah dalam keluarga TKW adalah alih peran, laissez-faire, transaksional, dan afiliasi. Kedua, adanya beberapa faktor pendorong dan penghambat pembentukan karakter religius pada anak. Faktor-faktor tersebut adalah struktur lingkungan fisik, lingkungan sosial, lingkungan pendidikan, suasana psikologis dalam keluarga, sosial budaya dalam keluarga, dan pengawasan orang tua terhadap anaknya. Keberhasilan faktor tersebut dipengarubi oleh perhatian orang tua. Orang tua yang peduli pada anakny cenderung sukeses di semua elemen struk.tur lingkungan. Di sisi lain, orang tua yang acub tak acub terhadap keluarganya cenderung gagal di semua elemen struktur.
\end{abstract}

Kata kunci: Orang Tua; Keluarga Nelayan; Keluarga TKW; Karakter Religius 
Parenting Styles of Fishermen ...

\section{A. Introduction}

The Indonesian nation is currently faced with the problem of moral decay that has occurred among its young generation. There is a lot of evidence that shows that this moral decay is done by children who are still in school, such as cheating, truancy, drugs, promiscuity, and brawls between students. In this case, there needs to be provisioning from an early age to control children's behavior to minimize delinquency in the future. The most important party in this matter is family.

The first education a child gets is education from the family. A good family education has a great potential to produce a qualified generation that will provide a positive impact on the society. ${ }^{1}$ According to Jalaluddin, family is the first field of education and the educators are his own parents. ${ }^{2}$ Parents (father and mother) are natural educators whom Allah has mandated to nurture, supervise, and guide their children, as Imam al-Ghazali, a Persian Muslim philosopher and theologian said:

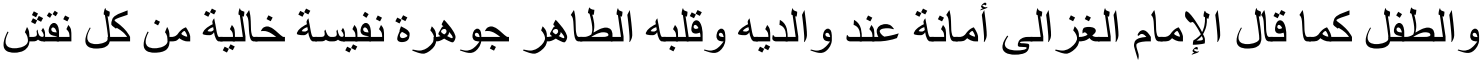

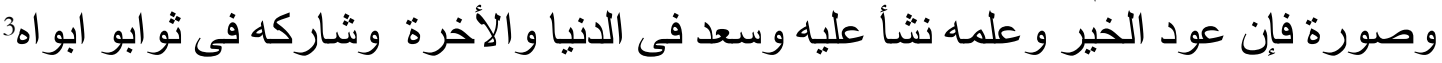 "A child is a mandate or a gift from Allah to both mother and father. The child's heart is still clean, like a precious jewel, devoid of all kinds of paintings and images. When the child is accustomed to good things, tanght to him good things, the child will grow up to be a good human being and will find happiness in this world and the hereafter. Both parents also get rewarded too."}

Parents (father and mother) have the same responsibility in caring for children.

The responsibility of a mother is as great as a father. Rasul SAW. has said:

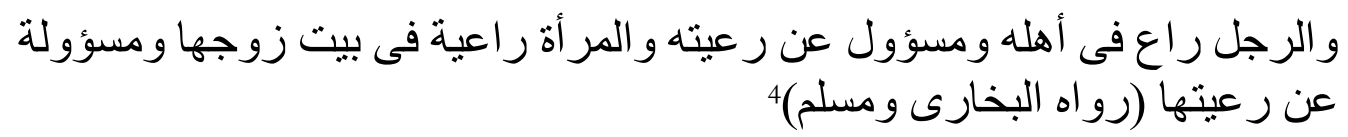

"A man is a shepherd (leader) in his family and he is responsible for that shepherding. And a woman is a shepherd (leader) in her husband's house and she is responsible for shepherding (whatever she leads)."

${ }^{1}$ M. Sofyan Al-Nashr, "Pendidikan Keluarga Dalam Pemikiran Sahal Mahfudh," BUANA GENDER: Jurnal Studi Gender dan Anak 1, no. 2 (December 30, 2016): 99.

2Jalaluddin, Psikologi Agama: Memahami Perilaku dengan Mengaplikasikan Prinsip-prinsip Psikologi, Jakarta: Rajawali Press, 2016, 255.

${ }^{3}$ Musthafa al-Ghalayini, Tdzah an-Nasyi'in: Kitab Akblak wa Adab waj Timaa', Cet. V, Bairut: atThab'ah al-Wathanivah, 1936, 189

${ }^{4}$ Nashih Ulwan, Tarbiyah al-Aulaad fi al-Islaam, Juz I, Kairo: Daar as-Salaam, 1996, 145. 
Thus, it is clear that the role of parents can no longer be ignored in family education. Education is the process of humanization. ${ }^{5} \mathrm{~A}$ harmonious family education from father and mother will help children achieve their development. Therefore, a father and mother need to determine the right family parenting style as a guide in educating their children. In Indonesian, parenting styles consists of three words, namely the pattern, foster and family. According to a Large Indonesian Dictionary (KBBI), Pattern means a fixed style, model, system, work method, form (structure). ${ }^{6}$ Meanwhile, the word foster includes all aspects related to maintenance, care, support, and assistance so that people can stand and live their lives in a healthy manner. ${ }^{7}$ While the definition of family is as follows:

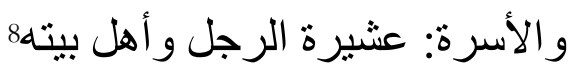

Family: someone's relatives, residents of his house.

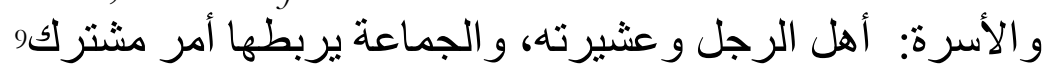

Family: residents of a person's house, their relatives and groups with whom they bave a cooperative relationship

From this explanation, it can be understood that parenting style means the habits of parents (father and mother) in leading, caring for, and guiding children in the family. That the family has a role in educating, teaching knowledge, and evaluating every attitude and behavior of elementary school students as long as he was in the scope of the family, school, and community. ${ }^{10}$ Parenting style to create a generation that is aware of moral values is inseparable from religious signs. Islam in this case has provided limits on human behavior in all aspects, both from the social, cultural, economic, and moral aspects that have been regulated by Allah in his holy word which

5Zuhri, "Aksiologi Nilai Pendekatan dan Strategi Penanaman Nilai dalam Pendidikan Islam (Keadilan, Tolong Menolong, Tanggung Jawab)", Jurnal Islamic Review, Vol. 9 No. 1 (April 2020), 142.

${ }^{6}$ Pusat Bahasa Departemen Pendidikan Nasional, Kamus Besar Bahasa Indonesia, Cet IV, Jakarta: Balai Pustaka, 2007, 1029 2014, 50-51

${ }^{7}$ Bahri Djamarah, Pola Asub Orang Tua dan Komunikasi dalam Keluarga, Jakarta: Rineka Cipta,

${ }^{8}$ Abul Fadhal Jamaluddin Muhammad ibn Makram ibn Manzur al-Afriqi al-Misri, Lisan al-Arab, Jilid 4, Beirut: Daru Sadir, 1405 H, 20.

'Majma' al-Lughah al-'Arabiyyah, al-Mu'jam al-Wariz, Kairo: Dar al-Tsaqafah, 1411 H, 16.

${ }^{10}$ Hidar Amaruddin, dkk., "Peran Keluarga Dan Media Sosial Dalam Pembentukan Karakter Santun Siswa Di Sekolah Dasar", Jurnal Pendidikan Karakter, Vol. 10 No. 1 (April 2020), 33. 
Parenting Styles of Fishermen ...

is then used as a guide for human life. As has been confirmed by Allah SWT. in his words Sura Al-Jasiyyah verse 20 which reads:

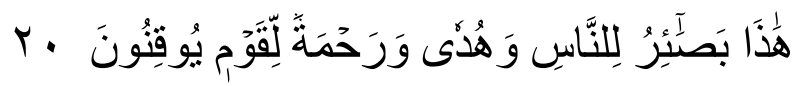

Translation: "These are clear evidences to men and a Guidance and Mercy to those of assured Faith (Sura Al-Jatsiyyah verse: 20)'11

so that the cultivation of religious character is very necessary to achieve a good personality of the children.

Thomas Lickona argues that character contains three main elements, namely knowing the good, desiring the good, and acting the good. ${ }^{12}$ Character education is the process of providing guidance to children or students to become fully human beings who have character in the dimensions of heart, mind, body, taste and intention. ${ }^{13}$ Meanwhile, the root word of 'religious' is a religion which comes from a foreign language religion as a form of a noun which means religion or belief in the existence of something natural power above humans. "Religious connected with religion or with a particular religion". ${ }^{14}$ So, religious character is a strong attitude in embracing and carrying out religious teachings and as a reflection of his obedience to the teachings of his religion.

But what happens when the role of one parent (father or mother) is neglected. As happened in the family of fishermen in the village of Bendar Juwana Pati and the families of female migrant workers (TKW) in Sundoluhur Kayen Pati. In general, the fishermen of Bendar Juwana Pati are large fishermen (modern fishermen) who work to catch fish using purse seine (in Indonesian = pukat cincin), long bag set net (in Indonesian $=$ pukat labuh), and bottom long line $($ in Indonesian = rawai dasar $)$. They go and return home uncertainly for months spending the night at sea with their shipmates. A father who works as a fisherman rarely meets his children because of

\footnotetext{
${ }^{11}$ Kementrian Agama Republik Indonesia, Alwasim Al-Qur'an Tajwid Kode, Transliterasi Per Kata, Terjemah Per Kata, Bekasi: Cipta Bagus Segara, 2013, 500.

12 Thomas Lickona, Educating for Character: How Our Schools Can Respect and Responsibility, New York: Bantam Books, 1991, 16

${ }^{13}$ Nailul Ghufron Aziz, "Relevansi Konseptual Model Hadits Pendidikan Karakter dalam Keluarga Perspektif Kitab Adab Al-Mufrad dan Tarbiyah Al-Aulad Fi Al-Islam Terhadap Konteks Kekinian," Islamic Review : Jurnal Riset dan Kajian Keislaman (2019).

${ }^{14}$ Martin H Manser, Oxford Advanced Learne's Dictionary, New York: Oxford University Press, $2006,357$.
} 
his busy life at sea. They can come together as a whole family for only a few days. The same is felt by the families of TKW in Sundoluhur Kayen Pati. In general, the female migrant workers (TKW) of Sundoluhur Kayen Pati work in Taiwan, Korea, Singapore, and Hong Kong. They go and return home for uncertain time, togetherness as a whole family of course does not happen. This makes the environment less conducive to build character for children.

The problem that will be revealed in this research is how is the parenting style of the families of fishermen in Bendar Juwana Pati and TKW in Sundoluhur Kayen Pati in instilling religious character in children and what are the driving and inhibiting factors of the parenting style of the families of fishermen in Bendar Juwana and TKW Sundoluhur Kayen in instilling religious character in children? The purpose of this study was to determine the parenting style and the factors inhibiting and encouraging the families of fishermen in Bendar Juwana Pati and the families of TKW in Sundoluhur Kayen Pati in instilling religious character in children. So far, there have been many studies that examine character education. However, this research focuses on the parenting style of the families of fishermen in Bendar Juwana Pati and TKW in Sundoluhur Kayen Pati in instilling religious character in children, so this research is deemed necessary.

\section{B. Method}

This study used a qualitative approach which aimed to describe and analyze the phenomena, events, social activities, attitudes, beliefs, perception, people's thoughts individually or in groups ${ }^{15}$, where data which is presented not in the form of numbers but in the form of words and representation ${ }^{16}$, so that the results of the research are in the form of descriptions and interpretations. The population in this study were the families of the fishermen in Bendar Village and the families of TKW Kayen Village. Determination of data sources in this study was carried out using snowball sampling. Snowball sampling is a technique of taking data sources, which at

\footnotetext{
60-61.

${ }_{16}$ Burhan Bungin, Metodologi Penelitian: Format-Format Kuantitatif dan Kualitatif, Surabaya: Airlangga University Press, 2005, 103.
}

${ }^{15}$ Nana Syaodih Sukmadinata, Metode Penelitian Pendidikan, Bandung: Remaja Rosdakarya, 2010, 
Parenting Styles of Fishermen ...

first are small, in number, over time they become larger. ${ }^{17}$ The data in this study were obtained through interviews, observation, and documentation. This research is a qualitative research, so that the data analysis is in the form of data reduction, data display, and conclusion drawing and verification.

\section{Results and Discussion}

Based on the results of the data that the researcher obtained about the parenting style of the families of fishermen and female migrant workers (TKW) in instilling religious character in children, it is stated that each family has different parenting styles and driving and inhibiting factors in instilling religious character in children. This can be seen from the results of interviews with the families of fishermen in Bendar Village and TKW from Kayen Village with the following explanation:

\section{The Parenting Style of Fishermen and Female Migrant Workers Families}

There are several types of parenting that is applied by the fishermen families in Bendar Village. The types of parenting include authoritarian, militaristic, democratic, purposeful, and paternalistic.

a. Authoritarian parenting

One of the parents who applies authoritarian parenting in instilling a religious character in their children is Mrs. Ning Tias Warastuti (Mrs. Tutik). He has two daughters named Ane and Trevi. The responsibility for educating children is fully delegated to $\mathrm{Bu}$ Tutik. This is because her husband goes sailing and is rarely home. Parents with this authoritarian type tend to be controllers, always impose their will on their children, are not open to children's opinions, find it difficult to accept suggestions and tend to impose their will on differences, too trusting in themselves so that they close the discussion. ${ }^{18}$

This is reflected in the results of the interview with Mrs. Tutik that she manages everything related to her children, especially in terms of fulfilling his obligations as a Muslim. In everyday life, Mrs. Tutik has rules that Ane and

${ }^{17}$ Sugiyono, Metode Penelitian Pendidikan: Pendekatan Kuantitatif, Kualitatif, dan R $\approx D$, Bandung: Alfabeta, 2010, 300.

${ }^{18}$ Bahri Djamarah, Pola Asub Orang Tua..., 60. 
Trevi must obey. If these rules are violated by them, then Mrs. Tutik will punish Ane in the form of confiscating her favorite bicycle for one week and confiscating her motorbike for one week as punishment for Trevi.

b. Militaristic parenting

One of the parents who applies militaristic parenting in instilling a religious character in their children is Mrs. Hj. Endang Setyorini (Mrs. Rini). She and her husband handle the responsibility of educating children. Because it happened that her husband had not gone sailing. He has children named Rida, Dina, and Krishna. This militaristic type of parent likes to rule. Without much dialogue, the children must obey their orders. It cannot be denied, must obey the orders and prohibitions. In certain circumstances, there is a threat, in a dangerous situation, this type is very appropriate to be used to move a child, because the child must quickly make the right decisions for his safety. ${ }^{19}$

This is shown from the results of the interview with her. She explained that her children always obeyed the rules and orders of her and her husband. Her children never violated the rules she applied, so she and her husband didn't need to punish them. In addition, they are always polite and gentle with their parents. Punishment is only given when they fight, whoever starts the fight will be punished.

c. Democratic parenting

Parents who apply democratic parenting in instilling a religious character in their children, namely Mrs. Muthmainnah (Mrs. Muth). He has three children named Naya, Qila, and Vano. Parents with this democratic type always prioritize common interests over individual children's interests. This type of democratic parenting expects children to share responsibilities, be able to develop their leadership potential, tolerate when children make mistakes and provide education to children so they don't make mistakes by not reducing the creativity of the child's initiative. ${ }^{20}$

\footnotetext{
${ }^{19}$ Bahri Djamarah, Pola Asub Orang Tua..., 67.

${ }^{20}$ Bahri Djamarah, Pola Asub Orang Tua..., 61.
} 
The results of the interview conducted by the researcher with Mrs. Muth stated that she still gave rules to her children, at least rules regarding time discipline. Even so, she still gave freedom to his children to develop their potential as long as this did not violate religious norms. As for if they violated, Bu Muth did not immediately punish them. She only reminded and admonished them so that the mistakes that happened did not happen again.

d. Purposeful parenting

One of the parents who applies the pattern of purposeful parenting in instilling a religious character in their children is Mrs. Anik Widarti (Mrs. Anik). Mrs. Anik and Mr. Wagiyo have three children, namely Cindy, Yongky, and Amira. Mr. Wagiyo, who works as a fisherman, makes him rarely at home, so that the responsibility for educating children is entirely delegated to Mrs. Anik. In educating children, Mrs. Anik applies the pattern of purposeful parenting, namely if she wants to move her child to do something, then there is a reward for her services in material form. So, because they want to get a fee, the child is motivated to do something that is ordered by his parents. This type of parenting is called purposeful (in Indonesian = pamrih) (in Sundanese $=$ gentong ngumes), because every work done has a material value. ${ }^{21}$

The results of the interview proved that Mrs. Anik's children were very difficult to control or command, such as orders to study, pray in congregation, go to the TPQ for reciting Qur'an, and get up early to pray at dawn. These orders will be carried out by her children when she has given a reward such as an additional allowance.

e. Paternalistic parenting

Parents with this paternalistic type act as fathers to their children in the form of educating, caring for, teaching, guiding, and advising. This type of parenting is called paternalistic because the parenting used is paternally. ${ }^{22}$ The

\footnotetext{
${ }^{21}$ Bahri Djamarah, Pola Asub Orang Tua..., 66.

${ }^{22}$ Bahri Djamarah, Pola Asub Orang Tua..., 62.
} 
character of the child formed from education in a family without a father is an independent child, not spoiled, and obedient. ${ }^{23}$

Parents who apply this parenting style in instilling a religious character in their children are all mothers from Bendar Village, Juwana District, Pati Regency whose husbands work as large fishermen or modern fishermen. So because the father is busy at sea for a long time, so that he rarely meets his child, the one who is tasked with educating, caring for, teaching, guiding, and advising the child in their daily life is the mother. The mother uses the influence of fatherhood to move the child towards the desired goal, although sometimes the approach taken is sentimental (easily influenced by feelings).

Similar to the families of fishermen, the families of TKW also have different parenting styles for each family. The parenting styles are:

a. Role-transfer parenting

This type of role-transferring model delegates the authority and responsibility of parents to children. This parenting style is used by parents to provide opportunities for children to carry out certain tasks and roles. Parents only facilitate and help when the solution to the problem is not found by the children. Although they are not given detailed instructions on what to do, the responsibility and decision-making process is largely left to the children. $^{24}$

One of the parents who adopted the role-transferring parenting style in instilling a religious character in their children, namely Mr. Kusnadi. Mr. Kusnadi and Mrs. Istianah have two children named Ghifari and Ghazali, both of whom are schooled at the Islamic boarding school. Directly, the responsibility of parents in educating their children at home is completely transferred to the boarding caregiver.

b. Laissez Faire parenting

${ }^{23}$ Novia Nusti Nurlatifah, dkk., "Pendidikan Karakter Anak Usia Dini Pada Keluarga Tanpa Ayah", Jurnal Edukids, Vol. 17 No. 1 (April 2020), 42.

${ }^{24}$ Bahri Djamarah, Pola Asub Orang Tua..., 65. 
The laissez faire parenting is not based on rules, freedom of choice is open to children with little parental interference so that the freedom given is controlled. If there is no control from parents, then the child's behavior is uncontrollable, unorganized, and apathetic, because the child feels he does not have the goals and objectives to be achieved. Communication from parents tends to act as a connector that links the contribution of thoughts from family members. ${ }^{25}$ Parent who practices parenting laissez faire in instilling a religious character in his children is Mr. Muh. Zainudin. Mr. Muh. Zainudin and Mrs. Mustaqimah have one daughter Maihun Rizqina (Maihun) class X of SMA Rifaiyah Sundoluhur and one son named Wildan Dwika Mahendra (Wildan) class VI of MI Miftahul Muhtadin Sundoluhur.

The results of the interview indicated that his two children tended to disobey his orders. This is due to the lack of intensive control from parents to children. Besides Mrs. Mustaqimah who works as a TKW, he also admits that he has not been able to give examples to his children directly. The main reason is because he works as a farmer who has to be in the fields all day long, so he has very limited time to keep the children.

c. Transaction parenting

This type of transaction parenting always makes an agreement (transaction), between the parent and the child to make an agreement of every action that is taken. Parents want their children to comply in the form of carrying out the agreed agreement. There are certain sanctions imposed on children, if at any time the child violates the agreement. ${ }^{26}$ One parent who applies transaction parenting in instilling a religious character in his child is Mr. Rustam Santiko. Mr. Rustam Santiko and Mrs. Hefi Kristiana only have one daughter, Naura Arsyafatur Rahma (Naura) class XI at SMA Rifaiyah Sundoluhur.

25Bahri Djamarah, Pola Asub Orang Tua..., 62.

26Bahri Djamarah, Pola Asub Orang Tua..., 64. 
The results of the interview showed that Mr. Rustam's family entrusted Naura to her uncle and aunt. Mrs. Hefi works as a TKW and Mr. Rustam works as a distributor driver who often leaves the house for several days to deposit goods outside Java, so Naura has to be entrusted to his uncle and aunt. When Mr. Rustam and Mrs. Hefi went to carry out their work, they made an agreement with Naura to obey the rules given by her uncle and aunt. If the rule is punished, then Mr. Rustam will punish her himself or hand over the punishment to her uncle and aunt.

d. Affiliation parenting

The affiliation parenting is a type of parental leadership that promotes harmony, relationships, and builds cooperation with children through merging. This type tries to build a strong bond between parent and child, seeks to create feelings of love, builds trust and loyalty between parent and child. The intimacy between parents and children is very harmonious. ${ }^{27}$ One of the parents who applies this parenting in instilling a religious character in his child is Mr. Solikin. Mr. Solikin and Mrs. Nuriah only have one daughter, Selly Alfionika (Selly) class IX at MTs Miftahul Muhtadin Sundoluhur.

From the results of the interview conducted by the researcher, it can be understood that the family structure created by Pak Solikin shows an era of relationship between parents and children. It can be said that Mr. Solikin and Selly have a high emotional bond. This can be proven by the existence of tolerance between the two as well as a sense of mutual understanding, so that Selly never objected when Mr. Solikin ordered something. As a result, it will be very easy for Mr. Solikin to form a religious character in Selly according to what he hopes.

\section{Driving and Inhibiting Factors of Parenting Styles for the Families of} Fishermen and TKW in Instilling Religious Character in Children

Parenting styles in instilling religious character in their children are factual and essential in life as a whole (entity). Therefore, the data selection was carried

${ }^{27}$ Bahri Djamarah, Pola Asub Orang Tua..., 63. 
Parenting Styles of Fishermen ...

out for the sharpness of the analysis for the sake of theoretical and practical guidance. ${ }^{28}$ Based on the results of interviews and observations that the researcher has done, the families of fishermen and TKW have the same driving and inhibiting factors in instilling religious character in children. The factors are:

a. The structure of the physical environment

The home environment which is decorated with Islamic identities such as calligraphy, prayer places, and the location of the house close to the mosque or musola can motivate family members to be more active in carrying out worship. This was exemplified in the families of Mrs. Rini, Mrs. Muth, Mrs. Tutik, Mr. Kusnadi, and Mr. Solikin where an Islamic atmosphere was created in their houses.

On the other hand, a house that does not create an Islamic atmosphere, does not have a place of worship, is located far from the mosque or musola and far from the TPQ will make family members feel discouraged to worship, besides that the children are also not motivated to go to the TPQ for reciting Qur'an. This condition is reflected in the families of Mrs. Anik, Mr. Zainudin, and Mr. Rustam.

b. The structure of the social environment

Good interaction within the family will foster a sense of mutual understanding. In this case, parental figures are needed in everyday life. Good interactions that exist in a family can create mutual respect, so that they can help parents in shaping the religious character of their children. As has been implemented in the family of Mrs. Rini, Mrs. Muth, Mrs. Tutik, Mr. Kusnadi, and Mr. Solikin who are always there when the child is in need. Even if they have limited time, they will try to spend that quality time hanging out with their families. Apart from that, the social environment also influences the inculcation of religious character. A religious environment can facilitate the formation of religious character in children. Meanwhile, an environment that is not religious, even an environment with a population that often deviates

28Shochib, Pola Asub Orang Tua, Jakarta: Rineka Cipta, 2014, 56. 
from religious norms, will inhibit efforts to form a religious character in children.

On the other hand, the absence of interaction between family members because each other's busyness will make the meeting feel awkward and strange. As a result, the messages and rules from the parents will be difficult to convey. This is what will inhibit the formation of religious character in children. This condition is experienced by the families of Mrs. Anik, Mr. Zainudin, and Mr. Rustam. It is very difficult for them to determine the time to gather with the family, so that there are only a few meetings between family members.

c. The structure of the educational environment

The educational environment in an organized family will help to form religious characters. For example, teaching children how to pray and read and write Qur'an from an early age. This will make it easier for children to deepen their religious knowledge when they are adults. On the other hand, children who are not familiar with the religion knowledge since childhood will find it very difficult to start learning religion from start when they reach adulthood. In addition, school mates also influence the formation of religious character. A good friend will bring the child to a good personality, on the other hand, a bad friend will bring the child to a bad personality as well. This is because a child will easily imitate the behavior of their peers. Like what Shaykh AzZarnuji has said in his poem:

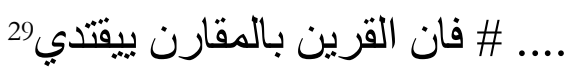
Which means that "in an association, the follow-up behavior often occurs."

d. The structure of the psychological atmosphere in the family

The psychological atmosphere of the family that can create attachment, intimacy, and high emotional ties will foster a high sense of empathy and sympathy, so that the process of forming the moralization of attachment can occur well. This process is the process of establishing good emotional bonds

${ }^{29} \mathrm{Az}$-Zarnuji, Ta’lim Al-Muta'allim, Surabaya:Nurul Huda, n.d, 15. 
Parenting Styles of Fishermen ...

in family relationships. This makes a child realize that he has a moral obligation, namely a sense of empathy and sympathy to obey all the rules and orders of the parents. On the other hand, the failed attachment moralization process will result in the child having a rebellious, selfish, and angry personality.

e. The structure of the socio-cultural in the family

Daily habits with Islamic nuances, such as time discipline in carrying out worship will help to form religious character properly. This is because children are accustomed to carrying out religious activities in daily life, so that these habits will turn into a necessity. On the other hand, Islamic culture that has never been applied in everyday life will be difficult if done immediately. As a result, the child feels that he has been dictated when performing worship. He did not feel that it was a habit, especially a necessity, and even felt that it was an order to burden them.

f. Parent control

Direct parental control will be more helpful in cultivating character. Like what Mr. H. Darmanto and Mrs. Rini's family has done, they both closely monitor their children's activities, so that all their children's activities are well controlled. On the other hand, parental controls that are only carried out periodically and indirectly can inhibit the formation of religious character in children. Like what happened to Mr. Zainudin's family where both parents are busy with their work, so that the children's behavior cannot be controlled properly.

\section{Conclusion}

The results of this study indicate that: First, the parenting styles used by several mothers in fishermen families are authoritarian, militaristic, democratic, purposeful, and paternalistic. The parenting styles used by fathers in TKW families are roletransfer, laissez-faire, transaction, and affiliation. Second, there are several driving and inhibiting factors in the formation of religious character in children. These factors are the structure of the physical environment, social environment, educational 
environment, psychological atmosphere in the family, socio-culture in the family, and parental control on their children. The success of these factors is influenced by parents' attention. Parents who care about their children tend to have success in all elements of environmental structures. On the other hand, parents who are indifferent to their families tend to fail in all structural elements.

\section{References}

Al-Ghalayini, Musthafa. 'Idzah an-Nasyi'in: Kitab Akblak wa Adab waj Timaa', Cet. V. Bairut: at-Thab'ah al-Wathaniyah, 1936.

Al-Misri, Abul Fadhal Jamaluddin Muhammad ibn Makram ibn Manzur al-Afriqi. Lisan al-Arab, Jilid 4. Beirut: Daru Sadir, 1405 H.

Al-Nashr, M. Sofyan. "Pendidikan Keluarga Dalam Pemikiran Sahal Mahfudh." BUANA GENDER : Jurnal Studi Gender dan Anak 1, no. 2 (December 30, 2016): 99.

Amaruddin, Hidar, dkk. "Peran Keluarga Dan Media Sosial Dalam Pembentukan Karakter Santun Siswa Di Sekolah Dasar.” Jurnal Pendidikan Karakter 10 (2020): 33.

Aziz, Nailul Ghufron. "Relevansi Konseptual Model Hadits Pendidikan Karakter Dalam Keluarga Perspektif Kitab Adab Al-Mufrad dan Tarbiyah Al-Aulad Fi AlIslam Terhadap Konteks Kekinian." Islamic Review : Jurnal Riset dan Kajian Keislaman (2019).

Az-Zarnuji. Ta'lim Al-Muta'allim. Surabaya: Nurul Huda, n.d.

Bungin, Burhan. Metodologi Penelitian: Format-Format Kuantitatif dan Kualitatif. Surabaya: Airlangga University Press, 2005.

Djamarah, Bahri. Pola Asub Orang Tua dan Komunikasi dalam Keluarga. Jakarta: Rineka Cipta, 2014.

Jalaluddin. Psikologi Agama: Memahami Perilaku dengan Mengaplikasikan Prinsip-prinsip Psikologi. Jakarta: Rajawali Press, 2016.

Kementrian Agama Republik Indonesia. Alwasim Al-Qur'an Tajwid Kode, Transliterasi Per Kata, Terjemah Per Kata. Bekasi: Cipta Bagus Segara, 2013.

Lickona, Thomas. Educating for Character: How Our Schools Can Respect and Responsibility. New York: Bantam Books, 1991.

Majma' al-Lughah al-'Arabiyyah. al-Mu'jam al-Wariz. Kairo: Dar al-Tsaqafah, $1411 \mathrm{H}$.

Manser, Martin H. Oxford Advanced Learne's Dictionary. New York: Oxford University Press, 2006. 
Parenting Styles of Fishermen ...

Nurlatifah, Novia Nusti, dkk. "Pendidikan Karakter Anak Usia Dini Pada Keluarga Tanpa Ayah.” Jurnal Edukids 17 (2020): 42.

Pusat Bahasa Departemen Pendidikan Nasional. Kamus Besar Bahasa Indonesia, Cet IV. Jakarta: Balai Pustaka, 2007.

Shochib. Pola Asub Orang Tua. Jakarta: Rineka Cipta, 2014.

Sugiyono. Metode Penelitian Pendidikan: Pendekatan Kuantitatif, Kualitatif, dan $\mathrm{R} \& D$. Bandung: Alfabeta, 2010.

Sukmadinata, Nana Syaodih. Metode Penelitian Pendidikan. Bandung: Remaja Rosdakarya, 2010.

Ulwan, Nashih. Tarbiyah al-Aulaad fi al-Islaam, Juг I. Kairo: Daar as-Salaam, 1996.

Zuhri. "Aksiologi Nilai Pendekatan dan Strategi Penanaman Nilai dalam Pendidikan Islam (Keadilan, Tolong Menolong, Tanggung Jawab)." Jurnal Islamic Review 9 (2020): 142 